\title{
Lead uptake and tolerance of Ricinus communis L.
}

\author{
Solange Romeiro', Ana M.M.A. Lagôa ${ }^{1, *}$, Pedro R. Furlani², Cleide A. de Abreu, Mônica F. de \\ Abreu $^{2}$ and Norma M. Erismann ${ }^{1}$
}

${ }^{1}$ Centro de Ecofiosiologia e Biofísica, ${ }^{2}$ Centro de Solos, Instituto Agronômico, 13001-970 Campinas, SP, Brasil. *Corresponding author:alagoa@iac.sp.gov.br

Received: 17 July 2006; Returned for revision: 16 September 2006; Accepted: 05 March 2007

Phytoextraction is an important technique used for the decontamination of areas polluted by lead. Consequently, an understanding of the physiological responses to tolerance of tropical species subjected to increasing levels of contamination is fundamental before considering their use as phytoextractors in contaminated areas. The objective of this study was to assess the lead $(\mathrm{Pb})$ uptake and the tolerance of Ricinus communis L. The plants were cultivated in nutrient solution in a greenhouse under controlled conditions. Lead was tested at concentrations of 0, 100, 200 and 400 $\mu \mathrm{mol} \mathrm{L}{ }^{-1}$. The experimental set-up was a block design, using a $4 \times 1$ factorial scheme, with three replicates. Biometric analyses, photosynthesis rates, and $\mathrm{Pb}$ content in the nutritive solution as well as in roots and shoots were performed. In conclusion, $R$. communis $\mathrm{L}$ is a hyperaccumulator species for $\mathrm{Pb}$ and presents tolerance properties in lead light concentration.

Key words: castor bean, heavy metal, lead, phytoremediation

Pontencial fitoextrator de Ricinus communis L. para chumbo: A fitoextração é uma técnica remediadora importante para áreas contaminadas por chumbo $(\mathrm{Pb})$, sendo importantes os estudos que relacionam a tolerância de espécies de clima tropical, desenvolvidas em níveis crescentes de contaminação, com a sua fisiologia, para que possam ser cultivadas como fitoextratoras em áreas contaminadas. Este trabalho teve o objetivo de estudar a espécie Ricinus communis L. como potencial fitoextratora de $\mathrm{Pb}$. As plantas foram cultivadas em solução nutritiva, em casa de vegetação, sob condições semi-controladas. Testaram-se as concentrações $0,100,200$ e $400 \mu \mathrm{mol} \mathrm{Pb} \mathrm{L}{ }^{-1}$. Os experimentos foram instalados em blocos ao acaso, em esquema fatorial 4 x 1, com três repetições. Foram realizadas análises biométricas e medidas as taxas de fotossíntese, bem como as concentrações de $\mathrm{Pb}$ na solução nutritiva, nas raízes e na parte aérea das plantas. Concluiu-se que $R$. communis $\mathrm{L}$ é uma espécie hiperacumuladora e apresenta tolerância ao $\mathrm{Pb}$ em baixas concentrações. Palavras-chave: chumbo, fitorremediação, mamona, metal pesado

\section{INTRODUCTION}

The intense and inadequate use of fertilizers and pesticides in the soil, coupled with the increase in industrial activity and mining are the main reasons for the contamination of soil, waterways and the water table by heavy metals (Malavolta, 1994). Among the existing pollutants, lead $(\mathrm{Pb})$ is the major contaminant of the soil (Gratão et al., 2005) poising significant environmental problems (Shen et al., 2002), including the risk of poisoning for humans and especially children (Lasat, 2002).

In November 2006, the Technology and Environmental Sanitation Company of the São Paulo State, Brazil (CETESB) reported the existence of 1822 (238 with metals) contaminated areas in the State of São Paulo. Brazilian legislation requires, however, as in the majority of other countries, that areas degraded by pollution be decontaminated in order to reduce the risk to both the population and environment (CETESB, 2006).

Lead absorption is regulated by $\mathrm{pH}$, cation exchange capacity of the soil, as well as by exudation and physicochemical parameters (Alloway, 1992; Parker et al., 1995; Lasat, 2000). Absorption by roots from the soil occurs via the plasma membrane, probably involving cationic channels such as calcium channels. Roots are capable of accumulating significant quantities of this heavy metal and simultaneously restrict its translocation 
to the shoot (Lane and Martin, 1977). The retention of $\mathrm{Pb}$ in roots involves binding to the cell wall and extracellular precipitation, mainly in the form of lead carbonate, which is deposited in the cell wall. At low concentration, $\mathrm{Pb}$ can move through root tissue, mainly via the apoplast and radially through the cortex where it accumulates near the endoderm. The endoderm acts as a partial barrier to the translocation of $\mathrm{Pb}$ through the root to the shoot. This may be one of the reasons for the much greater accumulation of $\mathrm{Pb}$ in roots than in shoots (Jones et al., 1973; Verma and Dubey, 2003). In a study using three cultivars of lettuce, Michalska (2001) showed that $0.5 \mathrm{mM}$ $\mathrm{Pb}$ in the nutrient solution resulted in greater $\mathrm{Pb}$ accumulation in roots. Ultrastructural studies have revealed the presence of $\mathrm{Pb}$ mainly in the intercellular spaces, cell wall, and vacuoles with little deposited in the endoplasmatic reticulum, dictyosomes and vesicles derived from the dictyosomes. The cell wall and the vacuole together account for $96 \%$ of the $\mathrm{Pb}$ absorbed (Wierzbicka and Antosiewicz, 1993).

Excess $\mathrm{Pb}$ causes a variety of toxicity symptoms in plants, such as reduced growth, chlorosis and darkening of the root system. Inhibition of root growth appears to result from $\mathrm{Pb}$-induced inhibition of cell division of the root meristem (Eun et al., 2000). Lead inhibits photosynthesis, alters the mineral nutrition and water balance, modifies hormone levels and affects the structure and permeability of the plasma membrane (Sharma and Dubey, 2005).

Plants pump water, solutes and organic matter from the surrounding medium as part of their natural physiological processes. This potential can be explored to stabilize, remove or breakdown contaminants in the soil (Robinson et al., 2003). In this respect, phytoextraction, a technique that uses hyperaccumulator plants to remove metals from the soil, stands out among other forms of phytoremediation of soils contaminated by heavy metals (Khan et al., 2000).

Phytoremediaton involves several steps: transfer of metals from the bulk soil to the roots surfaces, uptake into the roots and translocation to the shoots. Nutrient solution experiments address the latter two steps (Tandy et al., 2005). An alternative means of selecting plants with potential for phytoextraction is through the use of nutrient solutions for the growth of the plants. Such a procedure allows an adequate control of metal availability, and a consistent interpretation of the plant response. The technique of growing plants with nutrient solution is a well-established procedure for the evaluation of plant tolerance to a great variety of elements with a potential for phytotoxicity (Furlani and Clarck, 1981; Mcquattie and Schier, 1990; Alva and Chen, 1995).

Plants of the families Brassicaceae, Euphorbiaceae, Asteraceae, Lamiaceae e Scrophulariaceae have been identified as having potential for the extraction of lead from the soil (USEPA, 2003). According to Tang et al. (2001), the species Elsholtzia haichowensis and Commelina communis, during growth in hydroponic solution containing 66-224 mg Pb kg-1 accumulated $\mathrm{Pb}$ in greater concentration in the roots than in the shoots. Boonyapookana et al. (2005) studied of the hyperaccumulation potential for $\mathrm{Pb}$ of sunflower, tobacco and vetiver, and concluded that all three accumulated $\mathrm{Pb}$ in their leaves and stems, but the former was the most efficient accumulator.

The majority of plants that are known to be able to of $\mathrm{Pb}$ phytoextraction are from temperate climates (Accioly and Siqueira, 2000). In view of the importance of phytoextraction as a technique for phytoremediation of areas contaminated by lead, the search for tropical plant species that are tolerant to this metal becomes essential. Therefore, the aim of the present investigation was to study the response of Ricinus communis $\mathrm{L}$. to $\mathrm{Pb}$ and investigate its lead uptake and tolerance properties with regard to this heavy metal.

\section{MATERIAL AND METHODS}

The experiments were carried out at the Central Experimental Centre of the Agronomy Institute situated in the

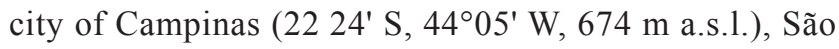
Paulo State, Brazil, from 26 March 2004 to 04 May 2004. Plants were grown hydroponically in a greenhouse in nutrient solution under controlled conditions of temperature, with mean temperature of $28 / 22^{\circ} \mathrm{C}$ (day/ night). The experimental set-up was a randomized block design, using a $4 \times 1$ factorial scheme with three replicates. Castor bean ( $R$. communis L.) plants were cultivated with solutions containing $0,100,200$ and 400 $\mu \mathrm{mol} \mathrm{Pb} \mathrm{L}{ }^{-1}$, supplied as lead acetate, with five plants per replicate. 
Seeds were germinated on moist filter-paper (CEL-065) and kept in a germination chamber at $20-35^{\circ} \mathrm{C}$ for $6 \mathrm{~d}$, according to established rules for the analysis of seeds (Brasil, 1992). After $7 \mathrm{~d}$ the seedlings were transferred to pots containing nutrient solution (Furlani and Furlani, 1988), aerated continuously by compressed air through porous stones. After $11 \mathrm{~d}$ the nutrient solution was replaced by another nutrient solution containing different concentrations of lead. Eight days after initiating the $\mathrm{Pb}$ treatments, three plants of each treatment were selected and labelled for the measurements of height, taken at 6-d intervals for a total of four measurements. Twenty-four days after being placed in the hydroponic system, the rates of $\mathrm{CO}_{2}$ uptake and the stomatal conductance to water vapour were measured using a portable infra red gas analyser (Li 6200, LiCor, Nebraska, USA). The same plants used for height measurements were also used for leaf area measurements, using an area meter (model L. I 3.100 SR, LiCor, Nebraska, USA).

Plants were exposed to $\mathrm{Pb}$ for a period of $28 \mathrm{~d}$, maintaining the nutrient solution $\mathrm{pH}$ at 5.5. At harvest, the shoots and roots were separated, washed with deionized water, and dried to constant mass in an oven $\left(65-75^{\circ} \mathrm{C}\right)$. The dried material was then ground in a Wiley mill, using a $1 \mathrm{~mm}$ mesh sieve. For $\mathrm{Pb}$ analysis the powdered material was dry digested by incineration and after solubilizing the ashes in $\mathrm{HCl}, \mathrm{Pb}$ was determined by inductively coupled plasma optical emission spectrometry (ICP - OES - model JY50P - Jobin Yvon, Longjumeau, France). Data were subjected to an analysis of variance and means were compared using Tukey's test, at $P<0.05$.

\section{RESULTS AND DISCUSSION}

There was a reduction in plant height with increasing concentrations of $\mathrm{Pb}$, irrespective of the time after application (Table 1). Similar results were observed by Tandy et al. (2005) for Helianthus annuus growing in nutrient solution with $\mathrm{Pb}\left(123 \mu \mathrm{mol} \mathrm{L} \mathrm{L}^{-1}\right)$. Table 1 also reveals that the difference in height for plants from the zero and $400 \mathrm{mmol} \mathrm{Pb} \mathrm{L}^{-1}$ treatments increased with time. This suggests that, over time, $\mathrm{Pb}$ must have interfered more strongly with the metabolic processes of the plant.

In this study, $\mathrm{Pb}$ treatments did decrease stomatal
Table 1. Plant height of castor bean (Ricinus communis L.) grown in hydroponics with different concentrations of lead. Within each column, means followed by a same letter did not differ significantly (Tukey's test, $P<0.05, n=3$ )

\begin{tabular}{ccccc}
\hline $\mathrm{Pb}$ & \multicolumn{4}{c}{ Days after treatment application } \\
\cline { 2 - 5 }$\left(\mu \mathrm{molL} \mathrm{L}^{-1}\right)$ & 8 & 14 & 20 & 26 \\
\hline 0 & $6.89 \mathrm{a}$ & $9.00 \mathrm{a}$ & $10.11 \mathrm{a}$ & $10.67 \mathrm{a}$ \\
100 & $7.00 \mathrm{a}$ & $7.67 \mathrm{a}$ & $8.44 \mathrm{ab}$ & $9.22 \mathrm{ab}$ \\
200 & $6.78 \mathrm{a}$ & $7.78 \mathrm{a}$ & $8.11 \mathrm{ab}$ & $8.56 \mathrm{ab}$ \\
400 & $7.00 \mathrm{a}$ & $7.55 \mathrm{a}$ & $7.78 \mathrm{~b}$ & $8.11 \mathrm{~b}$ \\
\hline
\end{tabular}

conductance to a greater extent than net photosynthetic rates (Figure 1A,B). Decreases in photosynthesis were relatively small, reaching statistical significance only in plants grown with $400 \mu \mathrm{mol} \mathrm{Pb} \mathrm{L}^{-1}$ (Figure 1A). It has been suggested that lead can alter photosynthesis through effects on stomata or directly on mesophyll cells in which both photochemical and biochemical reactions can be affected (Kosobrukhov et al., 2004). In barley seedlings, elevated levels of $\mathrm{Pb}$ in the soil reduce photosynthesis either through reduced carboxylase activity or through effects on the metabolites of the Calvin cycle (Stiborova et al., 1987). Consequently, the effect of $\mathrm{Pb}$ is perceived as a decrease in growth and development of the plant. Here, despite the sharp decreases in stomatal conductance, mesophyll limitations to photosynthesis cannot be ruled out, but, in any case, the present results suggest that inhibition of growth associated with decreases in photosynthesis in Pb-treated plants is rather unlike.

According to Kosobrukhov et al. (2004), application of $\mathrm{Pb}$ brings about a considerable decrease in dry mass accumulation of different plant parts. In Vetiver zizanioides and $V$. nemoralis the biomass accumulation of plants was reduced with increasing $\mathrm{Pb}$ concentrations (Chantachon, 2004). Nevertheless, for castor bean we observed a reduction in leaf area and dry mass of the shoots and roots up to the $\mathrm{Pb}$ concentration of $200 \mu \mathrm{mol}$ $\mathrm{L}^{-1}$, but additional increases in concentration did not alter these values further (Figures 2, 3A and 3B). On the other hand, beetroot (Beta vulgaris var. saccharifera) grown in hydroponics with $\mathrm{Pb}$ showed an increase in root dry mass without any change in shoots, even in $2 \mathrm{mM} \mathrm{Pb}$, resulting in an increased root to shoot ratio.(Larbi et al., 2002). For castor bean, there was no significant change in 

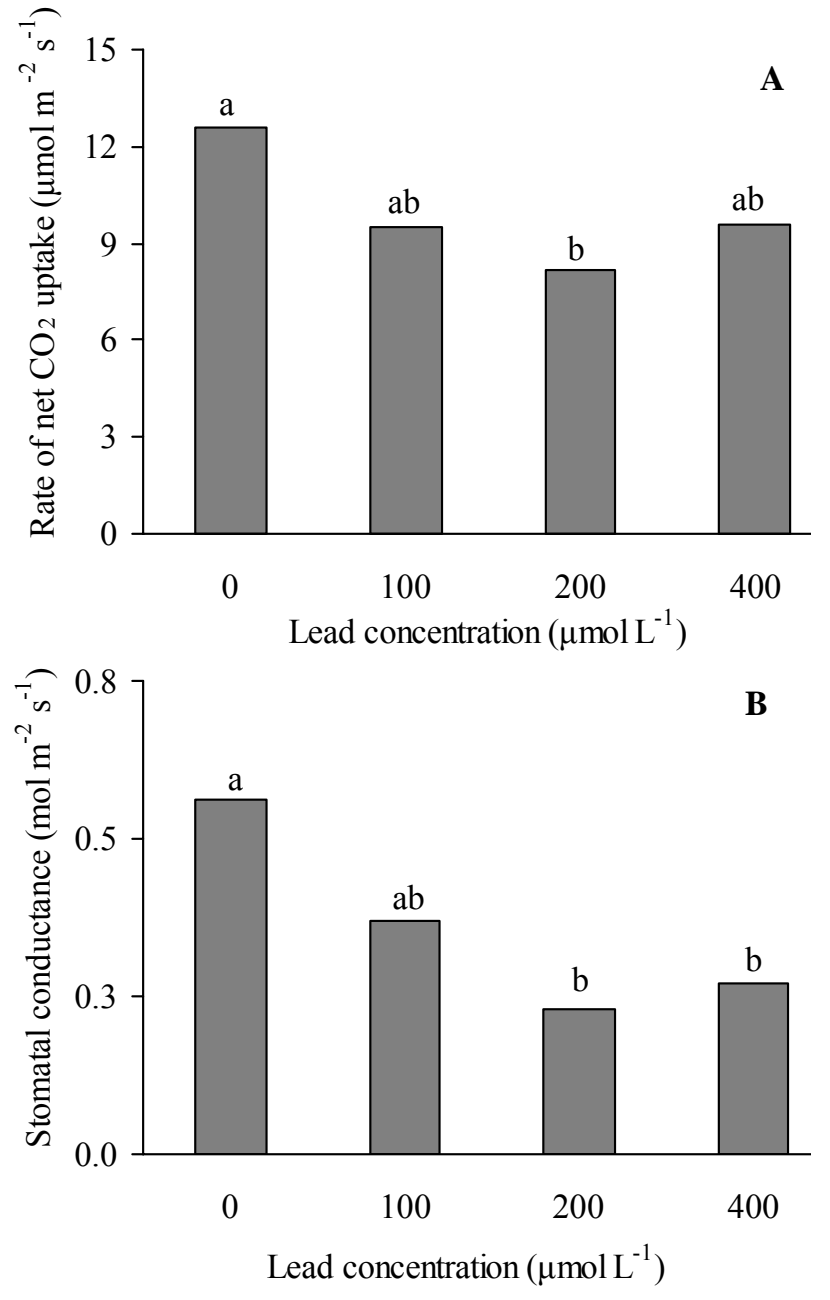

Figure 1. Rate of net $\mathrm{CO}_{2}$ uptake (A) and stomatal conductance (B) by castor bean (Ricinus communis L.) plants after growing in hydroponics with different concentrations of lead. Means followed by a same letter did not differ significantly (Tukey's test, $P<0.05, n=3$ ).

this ratio, which was about 0.65 regardless of $\mathrm{Pb}$ concentrations, thus suggesting parallel changes in growth of both roots and shoots. The inhibition of root growth may be due to a decrease in calcium in root tips, leading to a decrease in cell division or cell elongation (Haussling et al., 1988; Eun et al., 2000). The inhibition of growth of shoot may be due to a decrease in photosynthesis, in upsets mineral nutrition and water balance, changes hormonal status and affects membrane structure and permeability (Sharma and Dubey, 2005).

Data for residual $\mathrm{Pb}$ concentrations in the hydroponic nutrient solutions used for the growth of castor bean

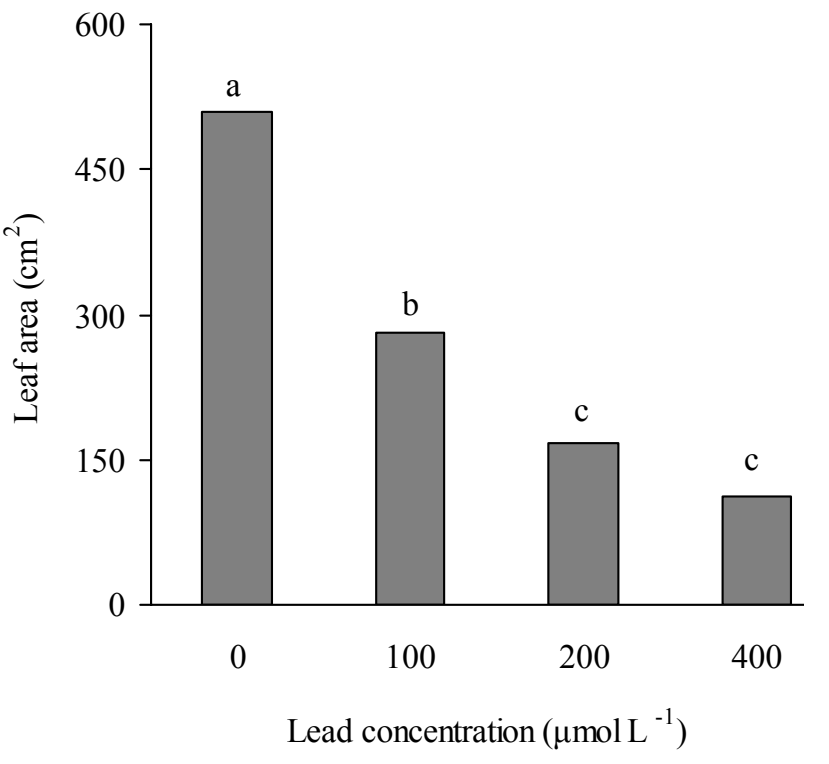

Figure 2. Leaf areas of castor bean (Ricinus communis L.) plants after growing for $40 \mathrm{~d}$ in hydroponics with different concentrations of lead. Statistic as in Figure 1.

revealed that, at the treatment concentrations of 100 and $200 \mu \mathrm{mol} \mathrm{Pb} \mathrm{L}^{-1}$, the plants removed almost all the $\mathrm{Pb}$ from the solution. At the highest concentration used, the removal of $\mathrm{Pb}$ was much lower compared to the others (Figure 4A). These data are consistent with the levels of $\mathrm{Pb}$ found in shoots and roots, where above $200 \mu \mathrm{mol} \mathrm{L}^{-1}$ translocation and absorption should have been diminished (Figures 4B,C).

The castor bean plants were able to accumulate large quantities of $\mathrm{Pb}$, especially in roots, demonstrating the high capacity for $\mathrm{Pb}$ absorption and accumulation of that organ (Figure 4C). Similar results were obtained for Carex rostrata, Eriophorum angustifolium and Phragmites australis grown in hydroponics (Stoltz and Greger, 2002). A high capacity for $\mathrm{Pb}$ retention in the roots with restricted translocation to the shoots was reported for Helianthus annus L. (Romeiro, 2005), Pinus radiata (Jarvis and Leung, 2002), spinach (Tsen et al., 2002) and Prosopis spp. (Aldrich et al., 2004).

According to Raskin et al. (1994), Pb hyperaccumulator plants are those capable of extracting and accumulating over $1.0 \mathrm{~g} \mathrm{~kg}^{-1} \mathrm{DM}$ in their tissues. Here we always found larger values, in the range 10.54 to $24.61 \mathrm{~g}$ $\mathrm{Pb} \mathrm{kg}^{-1}$ (Figure 5). Therefore, despite the occurrence of reduced growth, we may infer that castor bean has 


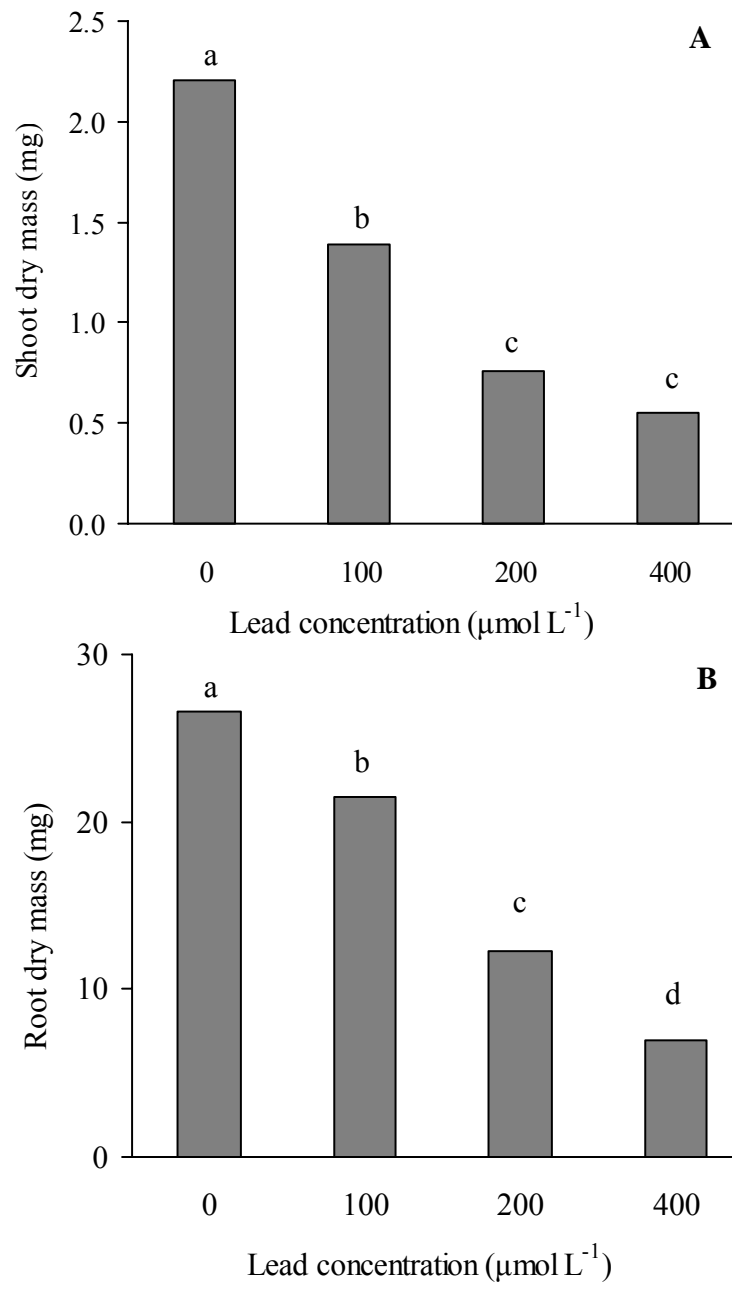

Figure 3. Dry mass of the shoot (A) and the roots (B) of castor bean (Ricinus communis L.) plants after growing for $40 \mathrm{~d}$ in hydroponics with different concentrations of lead. Statistic as in Figure 1.

hyperaccumulator characteristics for $\mathrm{Pb}$. This species is also considered as a hyperaccumulator and tolerant to several other heavy metals, including cadmium, zinc and nickel (Khan et al., 1998; Prasad, 2001). Taken together, these characteristics make castor bean plants as a potential plant species for heavy metal phytoextraction.

The ideal plant for phytoremediation should present rapid growth, high biomass production, deep roots, be easy to harvest, tolerate various metals and accumulate them in the shoots and/or the plant parts to be analyzed (Garbisu and Alkorta, 2001; Clemens et al., 2002). In the present investigation the greatest accumulation of $\mathrm{Pb}$ taken up from the nutrient solution was found in roots. In such cases, the use of complexing agents that increase
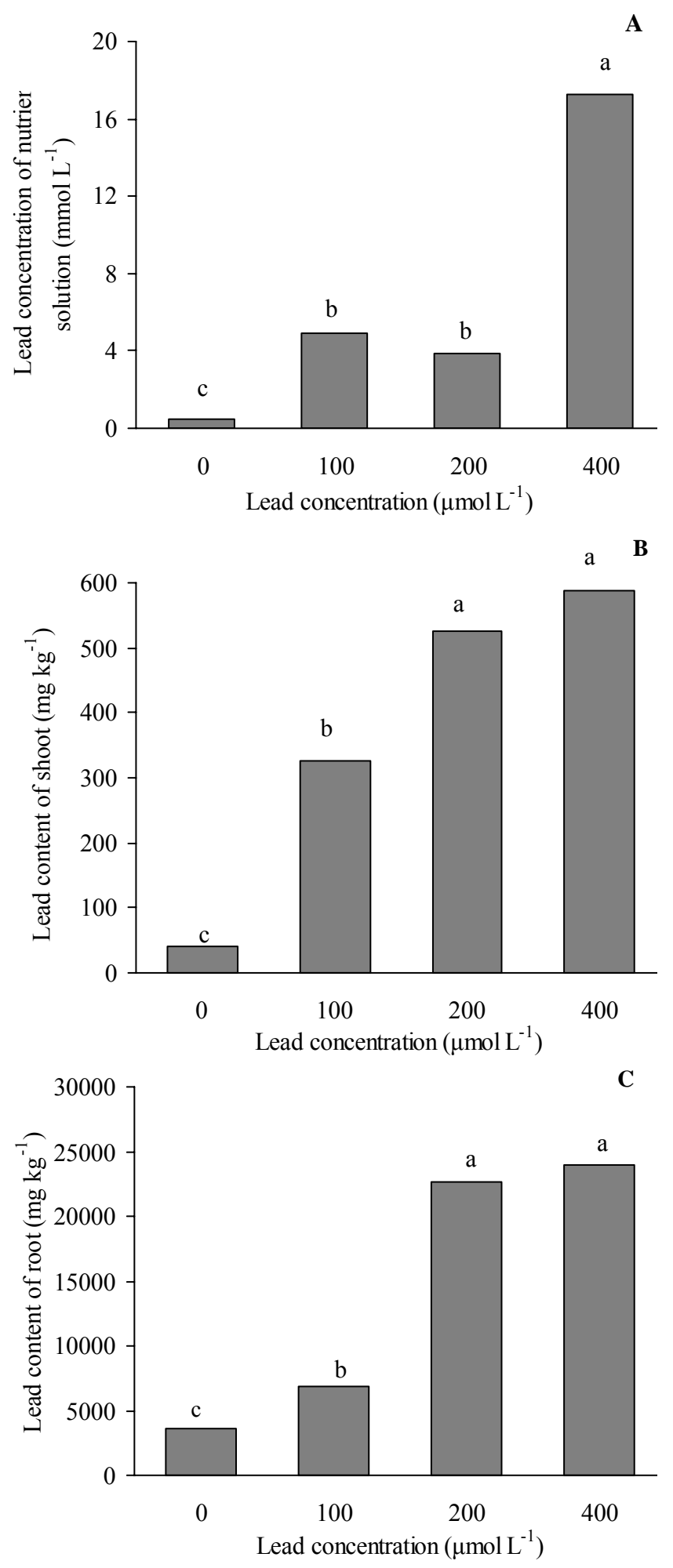

Figure 4. Lead concentration of the nutrient solution (A), as well as of shoots $(\mathbf{B})$ and roots $(\mathbf{C})$, after growing of castor bean (Ricinus communis L.) plants for $40 \mathrm{~d}$ in hydroponics with different concentrations of lead. Statistic as in Figure 1. 


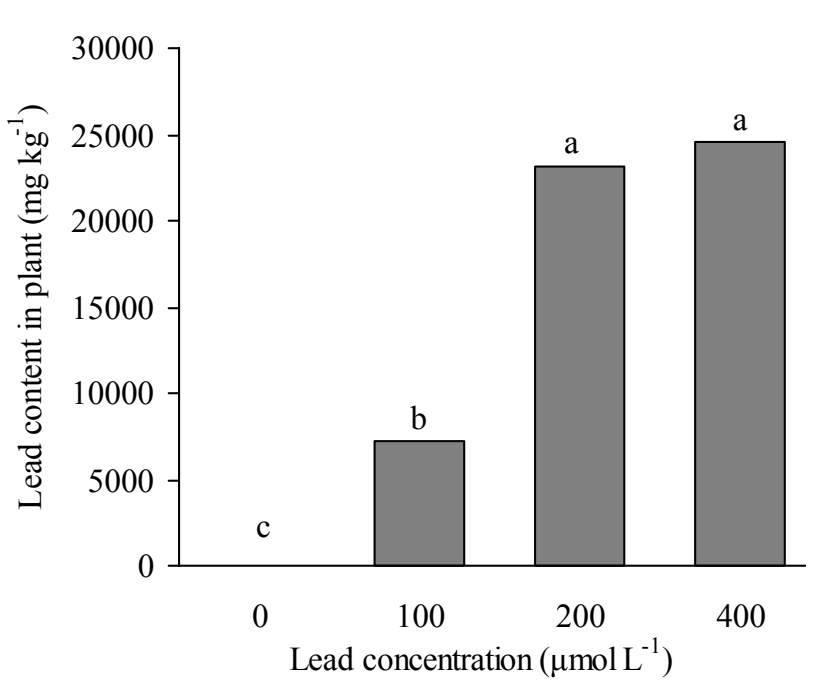

Figure 5. Lead concentration after growing of castor bean (Ricinus communis L.) plants for $40 \mathrm{~d}$ in hydroponics with different concentrations of lead. Statistic as in Figure 1.

the absorption of metals by the plants and at the same time are efficient in promoting translocation of $\mathrm{Pb}$ within the plant would be an advantage and has been described in the literature (Epstein et al.,1999). For instance, greater accumulation of $\mathrm{Pb}$ :EDDS (SS-EDDS is a biodegradable chelantin agent; Tandy et al., 2005) was found in the shoot of Helianthus annuus for contaminated hydroponics.

In conclusion, castor bean is a hyperaccumulator species for $\mathrm{Pb}$, presents tolerance properties in lead light concentration and may be tested under field conditions as a phytoextractor for this metal.

\section{REFERENCES}

Accioly AMA, Siqueira JO (2000) Contaminação química e biorremediação do solo. Top. Ciênc. Solo 1:299-351.

Aldrich MV, Elizev JT, Peralta-Videa JR, Gonzalez JH, GardeaTorresdey JL (2004) Lead uptake and the effects of EDTA on lead-tissue concentrations in the desert species mesquite (Prosopis spp.). Intern. J. Phytorem. 6:195-207.

Alva AK, Chen EQ (1995) Effects of external copper concentrations on uptake of trace elements by citrus seedlings. Soil Sci. 59:59-64.

Brasil (1992) Ministério da Agricultura e Reforma Agrária. Regras para análise de sementes. Departamento de Produção Vegetal, Brasília.

Boonyapookana B, Parkplan P, Techapinyawat S, DeLaune RD, Jugsujinda A (2005) Phytoaccumulation of lead by sunflower (Helianthus annuus), tobacco (Nicotiana tabacum), and vetiver (Vetiveria zizanioides). J. Environ. Sci. Health Part A-Toxic/Hazard. Subst. \& Environ. Engin. 40:117-137.

CETESB (2006) Companhia de tecnologia de saneamento ambiental. Relação de áreas contaminadas no Estado de São Paulo. Available in: <http://www.cetesb.sp.gov.br $>$ Accessed on January 28.

Chantachon S, Kruatrachue M, Pokethitiyook P, Upatham S, Tantanasarit S, Soonthornsarathool V (2004) Phytoextraction and accumulation of lead from contaminated soil by vetiver grass: Laboratory and simulated field study. Water Air Soil Pollut. 154:37-55.

Clemens S, Palmgren MG, Krämer U (2002) A long way ahead: understanding and engineering plant metal accumulation. Trends Plant Sci. 7:309-315.

Eun SO, Youn HS, Lee Y (2000) Lead disturbs microtubule organization in the root meristem of Zea mays. Physiol. Plant. 110:357-365.

Epstein AL, Gussman CD, Blaylock MJ, Yermiyahu U, Huang JW, Kapulnik Y, Orser, SC (1999) EDTA and PbEDTA accumulation in Brassica juncea grown in $\mathrm{Pb}-$ amended soil. Plant Soil 208: 87-94.

Furlani PR, Clarck RB (1981) Screening sorghum for Al tolerance in nutrients solution. Agron. J. 73:587-594.

Furlani AMC, Furlani PR (1988) Composição e pH de soluções nutritivas para estudos fisiológicos e seleção de plantas em condições nutricionais adversas, Instituto Agronômico. (Technical Bulletin, 121)

Garbisu C, Alkorta I (2001) Phytoextraction: a cost effective plant-based technology for the removal of metals from the environment. Biores. Technol. 77:229-236.

Gratão PL, Prasad MNV, Cardoso PF, Lea PJ, Azevedo RA (2005) Phytoremediation: green technology for the clean up of toxic metals in the environment. Braz. J. Plant Physiol. 17:53-64.

Cesare G, Stefano C, Camillo Z (2005) Phytoremediation of soil polluted by nickel using agricultural crops.Envion. Maneg. 36:1432-1009.

Haussling M, Jorns CA, Lehmbecker G, Hercht-Bucholz C, Marschner H (1988) Ion and water uptake in relation to root development of Norway spruce (Picea abies (L.) Karst). J. Plant Physiol. 133:486-491.

Henry JR (2000) An overview of the phytoremediation of lead and mercury. National Network of Environmental Management Studies (NNEMS), prepared for U.S. Environmental Protection Agency. Washington, D.C.

Jarvis MD, Leung DWM (2002) Chelated lead transport in Pinus radiata: an ultrastructural study. Environ. Exp. Bot. 48:21-32.

Jones LHP, Clement CR, Hopper MJ (1973) Lead uptake from solution by perennial ryegrass and its transport from roots to shoots. Plant Soil 38:403-414. 
Khan AG, Chaudhry TM, Hayes WJ, Khoo CS, Hill L, Fernandez R, Gallardo P (1998) Physical, chemical and biological characterisation of a steelworks waste site at Port Kembla, NSW Australia. Water Air Soil Pollut. 104:389-402.

Khan AG, Kuek C, Chaudhry, TM, Khoo CS, Hayes NJ (2000) Role of plants, mycorrhizae and phytochelators in heavy metal contaminated land remediation. Chemosphere 41:197-207.

Kosobrukhov A, Knyazeva I, Mudrik V (2004) Plantago major plants responses to increase content of lead in soil: growth and photosynthesis. Plant Growth Regul. 42:145-151.

Lane SD, Martin ES (1977) A histochemical investigation of lead uptake in Raphanus sativus. New Phytol. 79:281-286.

Larbi A, Morales F, Abadia A, Gogorcena Y, Lucena JJ, Abadia J (2002) Effects of $\mathrm{Cd}$ and $\mathrm{Pb}$ in sugar beet plants grown in nutrient solution: induced Fe deficiency and growth inhibition. Funct. Plant Biol. 29:1453-1464.

Lasat MM (2002) Phytoextraction of toxic metals: A review of biological mechanisms. J. Environ. Qual. 31:109-120.

Malavolta E (1994) Fertilizantes e seu impacto ambiental: micronutrientes e metais pesados - mitos, mistificação e fatos. Petroquímica, São Paulo.

Mcquattie CJ, Schier GA (1990) Response of red spruce seedlings to aluminum in nutrient solution: alteration in root anatomy. Can. J. For. Res. 20:1001-1011.

Michalska G (2001) Crossing effects of Belgian Landrace boars with Polish Large White, Hampshire and Duroc sows. Polish J. Food Nutr. Sci.10:139-141.

Prasad MNV (2001) Metals in the environment: analysis by biodiversity. New York, Marcel Dekker.

Raskin I, Kumar PN, Dushenkov JR, Salt DE (1994) Bioconcentration of heavy metals by plants. Curr. Opin. Biotechnol. 5:285-290.

Romeiro S (2005) Potencial de Ricinus communis L. Helianthus annus L. e Canavalia ensiformes L. como extratoras de chumbo em solução nutritiva. Campinas, Instituto Agronômico, Campinas. M.Sc. Thesis.
Robinson B, Green S, Mills T, Clothier B, van der Velde M, Laplane R, Fung L, Deurer M, Hurst S, Thayalakumaran T, van den Dijssel C (2003) Phytoremediation: using plants as biopumps to improve degraded environments. Aust. J. Soil Res. 41: 599-611.

Sharma P, Dubey RS (2005) Lead toxicity in plants. Braz. J. Plant Physiol. 17:35-52.

Shen ZG, Li XD, Wang CC, Chen HM, Chua H (2002) Lead phytoextraction from contaminated soil with highbiomass plant species. J. Environ. Qual. 31:1893-1900.

Stiborova M, Ditrichova M, Brezinova A (1987) Effect of heavy metal ions on growth and biochemical characteristics of photosynthesis of barley and maize seedlings. Biol. Plant. 29:453-467.

Stoltz E, Greger M (2002) Accumulation properties of As, $\mathrm{Cd}, \mathrm{Cu}, \mathrm{Pb}$ and $\mathrm{Zn}$ by four wetland plant species growing on submerged mine tailings. Environ. Exp. Bot. 47:271-280.

Tandy S, Schulin, R, Nowack, B (2005) The influence of EDDS on the uptake of heavy metals in hydroponically grown sunflowers. Chemosphere 62:1454-1463.

Tang S, Wilke BM, Brooks, RR (2001) Heavy metal uptake by metal-tolerant Elsholtzia haichowensis and Commelina communis from China. Commun. Soil Sci. Plant Anal. 32:895-905.

Tsen J, Su CKV, Tsen J, Su CC (2002) Absorption of various heavy metals by hydroponic water spinach. J. Agric. For. 50:1-11.

USEPA (2003) United States Environmental Protection Agency. Introduction to Phytoremediation. EPA/600/ R-99/107. Available on: http://clu-in.org/techpubs.htm $>$ Accessed on 13 February.

Verma S, Dubey RS (2003) Lead toxicity induces lipid peroxidation and alters the activities of antioxidant enzymes in growing rice plants. Plant Sci. 164:645-655.

Wierzbicka M, Antosiewicz D (1993) How lead can easily enter the food chain - a study of plant roots. Sci. Total Environ. 1 (Suppl.):423-429. 